\begin{tabular}{lllllllll}
$R$ & $E$ & $F$ & L & E & K & S & J & E \\
\hline
\end{tabular}

Ks. Jerzy Chmiel

\title{
ROZWAŻANIA W KRĘGU BIBLIJNYM
}

\author{
JEZUS NA REKACH SYMEONA
}

A gdy Rodzice wnosili Dzieciatko Jezus, aby postapić $z$ Nim wedtug zwyczaju Prawa, (Symeon) wzią Je w objęcia, błogosławit Boga... (Łk 2, 27n).

Według prawa Starego Testamentu ojciec brał w ramiona nowo narodzone dziecko, aby w ten sposób przyjąć je i uznać za swoje. Ten ojcowski gest powtarza Symeon jako znak przyjęcia Dziecka, które jest jego Panem. Dziwny w tym jakiś paradoks. Ten, który jest Stwórcą, staje się maleńkim dzieckiem na rękach starca. Zwraca na to uwagę Autor Listu do Hebrajczyków $(2,14)$ : Ponieważ zaś dzieci uczestnicza we krwi i ciele, dlatego $i$ On (tzn. Jezus) także bez żadnej różnicy stał się ich uczestnikiem, aby przez śmierć pokonać (...) diabła $i$ aby uwolnić tych wszystkich, którzy całe $\dot{z} y c i e ~ p r z e z$ bojaźń śmierci podlegli byli niewoli.

Dziecko na rękach starca staje się jego wybawicielem. Symeon oczekiwał śmierci, jak każdy stary człowiek. Lecz jego oczekiwanie nie było trwogą i lękiem, ale nadzieją. Jemu Duch Swięty objawit, że nie ujrzy śmierci, zanim nie zobaczy Mesjasza Pana. Błogosławione oczekiwanie śmierci. Ufał, że te wszystkie nadzieje, jakie ożywiały jego naród i jego samego, spełnią się. Wiedział, że musi przyjść ten moment, kiedy rozstanie się z tym światem, ale spodziewał się też, że to, dla czego żył i pracował, nie rozsypie się $\mathrm{w}$ proch, lecz przetrwa i wypełni się.

Za natchnieniem więc Ducha przyszedt do światyni.

Zastanów się, czy twoje chodzenie do kościoła, aby wziąć udział we Mszy św., jest przyjęciem Jezusa w ramiona? To znaczy, czy świadomy swojej przemijalności, że mogąc - powiedzmy to po prostu - w każdej chwili umrzeć, jesteś gotowy przyjąć to wszystko, dla czego żyjesz i istniejesz? Czy nie mówisz: a ja myślałem, że to będzie inaczej ... coś innego ... czegoś lepszego się spodziewałem...?

Byt to człowiek sprawiedliwy i pobożny - w ten sposób określa Ewangelista Symeona. To wyznacza pewien krąg ludzi, żyjących blisko Boga. To są ludzie błogosławieństw Jezusa: błogosławieni sprawiedliwi ... czystego serca... 


\section{ALLELUJA SYMEONA}

Teraz, o Władco, pozwól odejść słudze Twemu w pokoju. Uspokojony jest Symeon. Doczekał się tej chwili. Na rękach trzyma małe dziecię. Nie jest to ów potężny król-wybawiciel, którego wyczekiwały masy. To jest małe dziecko. Czy to nie złudzenie? Trzeba w tym dziecku zobaczyć tego, o którym marzył - Mesjasza. Symeon zobaczył. Dlatego może spokojnie odejść. Błogosławieństwo, jakie daje starcowi to Dziecko, to świadomość spokojnej śmierci, czyli odejścia do Boga. Dlatego śpiewa swoje ALLELUJA, czyli wychwalenie Boga.

W jednym ze swoich przemówień papież Jan Paweł I, którego Bóg tak nagle zabrał z tego świata, mówił :,Prawdziwe ALLELUJA - mówi w pewnym miejscu św. Augustyn - będziemy śpiewać w niebie. To będzie ALLELUJA pełnej miłości, bowiem to, które teraz śpiewamy, jest ALLELUJA miłości łaknącej, czyli nadziei ..."

Symeon śpiewał pieśń miłości łaknącej, ale zbliżał się do ALLELUJA pełnej miłości. Bo oczy moje ujrzaty Twoje zbawienie. Symeon zobaczył Jezusa, który oświeca każdego człowieka na świat przychodzącego. A Jezusa do świątyni przyniosła Maryja z Józefem. W liturgii greckiej nazywają Maryję „niosącą światło”. Takie niesienie światła wymaga jednak ofiary: a Twoja dusze miecz przeniknie prorokował w odniesieniu do Maryi Symeon. Maryja zdawała sobie z tego sprawę, dojrzewała wewnętrznie w tej szkole światłości, jaką jest Chrystus, dlatego Eukasz zapisze w swojej Ewangelii: a Matka Jezusa chowala wiernie wszystkie te wspomnienia w swym sercu ( $\mathrm{kk} 2,51 \mathrm{~b})$. Maryja jest dla nas wzorem, jak dojrzewać wewnętrznie do pełnego światła wiary.

Jean Guitton, wielki myśliciel francuski, tak się dzieli swoimi wrażeniami z lektury tej perykopy Łukaszowej:

„Odczytuję tekst Eukasza, który niewątpliwie słuchał jakiegoś świadka początku. Spostrzegam tam dziwny paradoks: oto w sercu Matki starzec odczuwa dramat przeznaczony dla Syna. Lecz ta Matka wyraża boleść całej społeczności. Jest więc figurą Kościoła. W ten sposób najpierwotniejsza tradycja, zebrana i przerobiona przez Łukasza, stawia nas w pionie ostatniego Soboru". (L'Évangile dans ma vie, Paris 1977 , s. 66).

\section{„JEŚLI CHCESZ, MOŻESZ MNIE OCZYŚCIĆ”}

\section{Chcę, bądź oczyszczony}

Księga Kapłańska (13-14) podaje pewne przepisy odnoszące się do postępowania $z$ trędowatymi. Przepisy te zostały ujęte $w$ formy rytualne, to znaczy wiążące się z kultem oddawanym Bogu. Porównując opis Księgi Kapłańskiej $\mathrm{z}$ opisem uzdrowienia trędowatego, zawartym w ewangelii Markowej (1, 40-45), spostrzegamy, że Jezus przekracza ramy rytualnego potraktowania chorego człowieka. 
On mu rzeczywiście przychodzi z pomocą: Chcę, bądź oczyszczony! Natychmiast trad go opuścił $i$ został oczyszczony. Ażeby przyjść nieszczęśliwemu człowiekowi z pomocą, Jezus dokonał cudu.

Zaczą opowiadać i rozgłaszać

Trędowaty nie posłuchał Jezusa, który polecił mu nic nie mówić o wydarzeniu. Przeciwnie, zaraz po wyjściu zaczął wiele opowiadać i rozgłaszać to, co zaszło, tak że Jezus nie mógł już jawnie pokazywać się w tych stronach. Dlaczego Jezus nie chcial rozgłosu? Bo nie uczynił cudu dla reklamy i poklasku tłumu, lecz jako znak swojej misji Mesjasza i przygotowanie do Zmartwychwstania. Psychologicznie rzecz biorąc nie można się dziwić uleczonemu, że nie siedział cicho. Dobrodziejstwo, jakiego doznał, było tak wielkie i niespodziewane, że nie potrafił milczeć. Jest stara zasada filozoficzna, którą filozofowie podawali po łacinie (bonum est diffusivum sui), a my możemy ją spolszczyć $\mathrm{w}$ ten sposób: dobro jest zaraźliwe, nie można go zamknác i schować tylko dla siebie, trzeba się $z$ nim podzielić.

\section{Apostot trędowatych}

Niedawno temu zmarł we Francji ciekawy człowiek. Dziennikarz z zawodu, spotkał pewnego razu w podróży poślubnej po Afryce grupę nieszczęśliwych Murzynów, trędowatych, wyrzuconych poza obręb ich wsi. Przejął się losem tych nieszczęśliwych, zrezygnował $z$ robienia kariery dziennikarskiej, aby służyć tym wyrzutkom ludzkości. Nazywał się Raoul Follereau. Tak jakby przyjął do siebie te słowa św. Pawła, które dzisiaj są do nas skierowane: Bądźcie naśladowcami moimi, tak jak ja jestem naśladowca Chrystusa (1 Kor 11, 1). Nie mógł czynić cudów, ale zaczął działać. W wyniku kilkudziesięcioletniej kampanii, którą prowadzł w obronie trędowatych, zrobiono wiele, świat się tym zainteresował, organizacje międzynarodowe śpieszą z pomocą nieszczęśliwym.

Follereau walczył nie tylko $\mathrm{z}$ trądem cielesnym, ale i $\mathrm{z}$ duchowym. Oto fragmenty jego wystąpień:

„Jestem pewien, że przyjdzie dzień, w którym nie będzie więcej głodu, nowotworów i wojen; ani dzieci bez miłości, ani starców bez opieki. Dzień, w którym wszyscy żyjący będą mieli prawo do życia". „Miłość jest rzuceniem światła oblicza Chrystusa na oblicze biedaka, cierpiącego, prześladowanego. Zbyt długo ludzie żyli jedni przy drugich. Dzisiaj ludzie mają świadomość, że winno się żyć razem. A my winniśmy im wskazywać, jak jutro żyć jedni dla drugich ... Ale co z tego, że uratujemy chorego od trądu, jeśli on zostanie mimo wszystko trędowatym".

Choroba trądu została już przez ludzkość w zasadzie opanowana. Ale pozostaje jeszcze trąd duchowy: zło, grzech, niesprawiedliwość, wyzysk, egoizm, przemoc, wygodnictwo, strach. Dlatego zwraca się do młodych $z$ apelem: „Ustanawiam jako moich spadkobierców młodzież całego świata, tę, która otrzymała dar wiary, tę, która tak się 
zachowuje, jakby nie wierzyła, i tę, która wierzy, że nie wierzy". Żarliwe słowa apostoła trędowatych, który wie z doświadczenia, że nie można nie mówić o tym, co dobre, tak jak nie mógł milczeć uleczony $z$ trądu w ewangelii, choć mu Jezus chwilowo zakazywał.

Modlitwa współczesnych trędowatych

„Panie, oto Twoi trędowaci,

bez rąk, z twarzami zniekształconymi,

odepchnięci, odrzuceni, nieczyści,

którzy niosą jak Twój krzyż całą nędzę świata.

Panie, oto prawdziwi trędowaci,

egoiści, bezbożni,

którzy żyją w bajorze,

wygodni, trwożliwi,

którzy marnują swoje życie.

Panie, to są prawdziwi trędowaci,

którzy Ciebie ukrzyżowali".

(R. Follereau)

\section{„WEŹMIJCIE DUCHA ŚWIĘTEGO”}

Duch pierwotnego Kościoła

Dzieje Apostolskie kręślą nam obraz pierwszych chrześcijan. Jeden duch $i$ jedno serce ożywiało wszystkich wierzacych. Apostotowie $z$ wielka moca świadczyli o zmartwychwstaniu Pana Jezusa. Zwróćmy uwagę na stosunek pierwszych chrześcijan do dóbr materialnych. Nie cierpieli oni biedy, można powiedzieć, że mieli się dobrze, ale dlatego, że wszystko mieli wspólne. Duch wspólnoty rozciągał się także na dobra materialne. Nikt ich nie zmuszał do takiej wspólnoty, czynili to dobrowolnie, z natchnienia Ducha.

Nie można budować wspólnoty społecznej bez uregulowania apetytu konsumpcji. Tragedią dzisiejszego rozbitego świata jest ogromna nierówność ekonomiczna. Zmarły niedawno angielski socjolog i ekonomista Fred Hirsch w swej najważniejszej pracy The Social Limits of Growth (Społeczne granice wzrostu, Harvard University Press 1976) pisał o błędnym kole: im więcej dane społeczeństwo produkuje i w tym upatruje swoją szczęśliwą przyszłość, tym bardziej staje się rozbite i sfrustrowane. Jedność społeczności chrześcijańskiej jest uwarunkowana jednomyślnością w rozwoju materialnym. Nie bogacenie się bez miary i potrzeby, nie kariera za wszelką cenę, ale wrażliwość na drugiego człowieka i jego potrzeby, tak aźeby nie rzeczy panowały nad człowiekiem, lecz człowiek nad rzeczami.

Wiara w Jezusa

Pierwszy List św. Jana jest jakby listem pasterskim Apostoła, umiłowanego ucznia Jezusa, nie tylko do swoich uczniów, ale i do nas. Istnieje ścisły związek między miłością a wiarą. Miłość bliź- 
niego wyzwala się w człowieku przez otwarcie się na drugiego człowieka. Taka miłość bliźniego prowadzi do Boga, który jest źródłem wszelkiej miłości, bo Sam jest Miłością. Taka miłość opiera się na wierze, która uznaje, że Jezus jest Bogiem.

Co to znaczy, że Jezus Chrystus przyszedł przez wodę i krew, i Ducha? Przez wodę, bo widzialnym znakiem i początkiem wiary jest chrzest wszczepiający nas w Chrystusa. Przez krew, bo żyjemy z Chrystusem przez znaki sakramentalne, ustanowione Jego zbawczą ofiarą, a w szczególności łączymy się z Nim przez Eucharystię. Przez Ducha, ponieważ jesteśmy dziećmi Bożymi, pieczętowani znakiem Ducha Swiętego: znakiem łaski sakramentalnej. Woda - krew - Duch to znaki naszej wiary.

\section{Znak Zmartwychwstania}

Niewierny Tomasz przeszedł do przysłowia. Ale stał się też symbolem silnej wiary: Pan mój i Bóg mój. Każdy człowiek przechodzi etap niewiernego Tomasza: pyta sie, zaczyna wątpić, jest na drodze zagubienia, jakże często rozpaczy. Przychodzi Jezus Zmartwychwstały i mówi niejako do nas: Weźmijcie Ducha Świętego, pokazuje nam Swój bok i ręce - ślady przebytej męki. Daje nam owe znaki wiary: wode - krew - Ducha, to znaczy całe bogactwo życia sakramentalnego. Sakramenty święte to nie martwe ryty, ale żywe znaki Zmartwychwstałego Pana, który nas zaprasza do silnej wiary: Blogosławieni, którzy nie wiedzieli, a uwierzyli.

Współczesna nauka potwierdziła autentyczność Całunu Turyńskiego. Wystawiony ostatnio (jesień 1978) na widok publiczny, przyciągał, fascynował, zniewalał. Jakieś świadectwo męki i zmartwychwstania Jezusa. Całun nie może nam udowodnić zmartwychwstania Jezusa, ale może nam pomóc $\mathrm{w}$ wierze. Korzystajmy $\mathrm{z}$ tych wszystkich znaków, jakie nam daje Bóg. Nie możemy już włożyć palców w rany Jezusa jak Tomasz, ale możemy dotknąć Boga przez naszą wiarę. 